\begin{tabular}{l|l} 
Jurnal Eksplorasi Akuntansi & $\begin{array}{l}\text { ISSN : 2656-3649 (Online) } \\
\text { hol. 1, No 3, Seri F, Agustus 2019, Hal 1541-1555 }\end{array}$
\end{tabular}

\title{
PENGARUH INTELLECTUAL CAPITAL TERHADAP NILAI PERUSAHAAN DENGAN PROFITABILITAS SEBAGAI VARIABEL INTERVENING
}

\author{
Atikah Juliani Putri' ${ }^{1}$ Henri Agustin², Nayang Helmayunita ${ }^{3}$ \\ 1) Alumni Jurusan Akuntansi Fakultas Ekonomi, Universitas Negeri Padang \\ 2,3)Jurusan Akuntansi Fakultas Ekonomi, Universitas Negeri Padang \\ *Korespondensi: atikahputri94@gmail.com
}

\begin{abstract}
This study aims to determine the effect of intellectual capital on firm value and profitability as an intervening variable. This research was conducted on finance companies listed on the Indonesia stock exchange in 2013-2017. The sample is determined by purposive sampling 48 finance companies are obtained. Technique of collecting data is done by documentation technique obtained through IDX official website: www.idx.co.id. Data analysis used is structural equation modeling (SEM) using SmartPLS software ver 3.2.7. The result of the research shows that (1) the intellectual capital positive effect on the firm value (2) the intellectual capital does no effect the firm value through profitability.
\end{abstract}

Keywords: Intellectual capital;Profitability; Partial Least Square

\section{How to cite (APA $6^{\text {th }}$ style)}

Putri, A.J., Agustin, H., \& Helmayunita, N. (2019). Pengaruh Intellectual Capital terhadap Nilai Perusahaan dengan Profitabilitas Sebagai Variabel Intervening. Jurnal Eksplorasi Akuntansi, 1(3), Seri F, 1541-1555.

\section{PENDAHULUAN}

Perusahaan didirikan dengan tujuan untuk dapat tumbuh dan berkembang dalam jangka waktu yang panjang. Perusahaan juga diharapkan mampu mengoptimalkan kinerja keuangan sesuai dengan yang telah direncanakan agar dapat mencapai nilai yang diinginkan oleh pemilik perusahaan. Semakin tinggi nilai yang dihasilkan oleh perusahaan semakin menggambarkan kesejahteraan para pemilik nya (stakeholder). Sehingga tujuan utama dari sebuah perusahaan tidak lagi hanya memaksimumkan laba namun lebih kepada memaksimalkan nilai perusahaan

Terdapat banyak faktor yang dapat mempengaruhi tinggi rendahnya nilai perusahaan, baik faktor internal maupun faktor eksternal perusahaan. Faktor internal dapat berasal dari dalam perusahaan itu sendiri, misalnya kurang bagusnya manajemen yang diterapkan dalam perusahaan, kurangnya pengetahuan atau skill yang dimiliki oleh perusahaan dalam mengelola keuangan perusahaan, manajer yang tidak mampu membaca peluang pasar, sehingga apa yang menjadi tujuan perusahaan tidak tercapai secara maksimal. Sedangkan faktor eksternal adalah faktor yang berasal dari luar perusahaan yang dapat mempengaruhi nilai perusahaan. Diantaranya adalah kebijakan ekonomi yang dikeluarkan pemerintah, kenaikan dollar, tingginya 
inflasi, hal ini dapat menyebabkan tidak tercapainya nilai perusahaan sesuai dengan yang diharapkan stakeholder (Atmaja, 2008).

Menurut Hermuningsih (2013) nilai perusahaan dapat diukur dengan Price Book Value (PBV), yaitu perbandingan antara harga saham dengan nilai buku saham. PBV yang tinggi akan meningkatkan kepercayaan pasar pada prospek perusahaan dan mengindikasikan kemakmuran pemegang saham. PBV juga dapat diartikan sebagai rasio yang menunjukkan apakah harga saham yang diperdagangkan overvalued atau undervalued dari nilai buku saham tersebut. Menurut Arsjah (2002), PBV merupakan salah satu rasio keuangan yang cukup representative untuk melihat penciptaan nilai oleh suatu perusahaan. Oleh karena itu dalam penelitian ini nilai perusahaan akan diukur dengan rasio Price to Book Value (PBV).

Nilai perusahaan jika dinilai dari fisik saja hasilnya tidak akan sesuai dengan nilai pasarnya karena ada nilai selain fisik atau intangible yang mempengaruhinya. Nilai itu muncul karena ada perbedaan antara harga saham dengan nilai buku aktiva yang dimiliki perusahaan. penghargaan lebih atas saham perusahaan dari investor tersebut diyakini disebabkan oleh intellectual capital (IC) yang dimiliki perusahaan (Sunarsih dan Mendra, 2012). Wu et al. (2008) dalam Hadiwijaya (2013), memberikan definisi IC dalam arti yang luas yaitu sebagai aset tak berwujud yang dimiliki oleh perusahaan. Menurut Nugroho (2012), intellectual capital adalah suatu pengetahuan dan kekayaan intelektual yang mampu menemukan peluang dan mengelola ancaman sehingga dapat mempengaruhi daya tahan dan keunggulan bersaing perusahaan.

Para peneliti secara umum membagi intellectual capital ke dalam tiga unsur utama yaitu human capital, struktural capital, dan customer capital. Ketiga unsur tersebut dipercaya dapat membangun intellectual capital yang mampu meningkatkan nilai perusahaan apabila dikelola dan dimanfaatkan secara optimal. Jika nilai perusahaan tinggi, investor akan memberi nilai lebih pada perusahaan dengan melakukan investasi. Dengan begitu semakin besar investasi yang dilakukan oleh para investor akan semakin meningkatkan pengelolaan intellectual capital oleh perusahaan.Informasi yang berasal dari pengelolaan intellectual capital diharapkan dapat membantu investor dalam menilai kemampuan perusahaan dengan lebih baik.

Profitabilitas merupakan rasio yang dapat menggambarkan kemampuan suatu perusahaan dalam memperoleh laba. Menurut Bringham dan Houston (2001), profitabilitas dapat dikatakan sebagai kemampuan perusahaan dalam menghasilkan laba bersih dari aktivitas yang dilakukan pada periode akuntansi. Tujuan investor menanamkan saham pada perusahaan adalah untuk mendapatkan return yang baik. Semakin tinggi kemampuan memperoleh laba maka semakin tinggi return yang diharapkan investor, sehingga menjadikan nilai perusahaan menjadi lebih baik. Pentingnya profitabilitas dapat dilihat dengan mempertimbangkan dampak yang berasal dari ketidakmampuan perusahaan mendapatkan laba yang maksimal untuk mendukung kegiatan operasionalnya. Ketika perusahaan memperoleh laba yang maksimal, maka akan berdampak terhadap peningkatan nilai perusahaan. Investor akan lebih tertarik untuk berinvestasi pada perusahaan dengan laba tinggi.

Penelitian tentang intellectual capital telah banyak dilakukan baik didalam negeri maupun di luar negeri dengan hasil yang beragam. Perbedaan penelitian ini dengan penelitian sebelumnya yaitu adanya profitabilitas sebagai variabel mediasi, perbedaan pengukuran variabel, perbedaan teknik analisis data dan alasan penting lainnya yaitu terdapat perbedaan hasil penelitian. Wicaksana (2011) dalam penelitiannya mengenai pengaruh intellectual capital terhadap pertumbuhan dan nilai pasar perusahaan pada perusahaan perbankan di bursa efek Indonesia menunjukkan hasil bahwa IC berpengaruh secara signifikan dan positif terhadap pertumbuhan dan nilai pasar perusahaan. Sunarsih dan Mendra (2012) berusaha menginvestigasi 
pengaruh IC terhadap nilai perusahaan dengan menggunakan kinerja keuangan sebagai variabel intervening. Hasil penelitian menunjukkan bahwa IC memiliki hubungan positif terhadap kinerja keuangan perusahaan, namun IC tidak berpengaruh secara langsung terhadap nilai perusahaan.

Penelitian bertujuan melihat apakah profitabilitas mampu memediasi hubungan intellectual capital dengan nilai perusahaan. Sampel dalam penelitian ini adalah perusahaan sektor keuangan yang terdaftar di BEI tahun 2013-2017. Berdasarkan uraian latar belakang di atas mengenai intellectual capital, nilai perusahaan dan profitabilitas maka peneliti tertarik untuk mengambil judul tentang "Pengaruh Intellectual Capital terhadap Nilai Perusahaan dengan Profitabilitas sebagai Variabel Intervening".

\section{KAJIAN TEORI}

\section{Teori Stakeholder}

Stakeholder theory menyatakan bahwa perusahaan bukanlah entitas yang hanya beroperasi untuk kepentingan perusahaan. Namun juga harus memberikan manfaat bagi stakeholder (pemegang saham, kreditor, konsumen, pemasok, analis, karyawan, pemerintah) (Ghozali dan Chairi 2007). Teori ini menjelaskan pentingnya perusahaan untuk memuaskan keinginan para stakeholder. Perusahaan akan bereaksi dengan melakukan aktivitas-aktivitas pengelolaan yang baik dan maksimal atas sumber-sumber ekonomi untuk mendorong kinerja keuangan dan nilai perusahaan sesuai dengan harapan dari para stakeholder.

Stakeholder theory juga menekankan bahwa stakeholder memiliki hak untuk memperoleh informasi mengenai aktivitas-aktivitas perusahaan tersebut yang juga dapat berpengaruh pada stakeholder. Tujuan utama dari teori stakeholder adalah untuk membantu manajemen perusahaan dalam meningkatkan penciptaan nilai sebagai dampak dari aktivitas yang dilakukan dan meminimalkan kerugian yang mungkin muncul bagi stakeholder. Stakeholder theory lebih menekankan akuntabilitas organisasi dibandingkan dengan kinerja keuangan atau ekonomi sederhana (Deegan, 2004).

\section{Resource Based Theory}

Resource based theory (RBT) atau teori berbasis sumber daya adalah suatu teori yang dikembangkan untuk menganalisis keunggulan bersaing suatu perusahaan yang menonjolkan keungulan pengetahuan (knowledge/learning economy) atau perekonomian yang mengandalkan asset-aset tak berwujud (intangible asset). Teori ini membahas mengenai sumberdaya yang dimiliki perusahaan, dan bagaimana perusahaan dapat mengembangkan keunggulan kompetitif dari sumberdaya yang dimilikinya. Guna mengembangkan keunggulan yang kompetitif perusahaan harus memiliki sumber daya dan kemampuan yang melebihi para kompetitornya (Cheng et al. 2010).

\section{Nilai Perusahaan}

Nilai perusahaan (Value Of The Firm) merupakan suatu kondisi tertentu yang telah dicapai oleh suatu perusahaan sebagai gambaran dari kepercayaan masyarakat terhadap perusahaan. Tinggi rendahnya nilai perusahaan dapat melambangkan kemakmuran pemegang saham. Semakin tinggi harga saham semakin tinggi nilai perusahaan.

Nilai perusahaan adalah harga yang tersedia dibayar oleh calon pembeli apabila perusahaan tersebut dijual (Husnan 2008). Menurut Harmono (2011), Nilai perusahaan dapat diukur melalui harga saham dipasar, berdasarkan terbentuknya harga saham perusahaan di pasar, yang merupakan refleksi penilaian publik terhadap kinerja perusahaan secara riil, karena harga 
merupakan bertemunya titik kestabilan kekuatan permintaan dan penawaran yang secara riil terjadi transaksi jual beli surat berharga dipasar modal antara penjual (emiten) dan investor, yang disebut equilibrium pasar.

Samuel (2000) dalam Agustina (2013) menjelaskan bahwa enterprise value (EV) yang juga dikenal sebagai firm value (nilai perusahaan) merupakan konsep penting bagi investor, karena merupakan indikator bagi pasar untuk menilai perusahaan secara keseluruhan. Nilai perusahaan dibentuk melalui indikator nilai pasar saham yang sangat dipengaruhi oleh peluangpeluang investasi. Adanya peluang investasi dapat meningkatkan nilai perusahaan. Nilai perusahaan juga dapat terlihat dari minat investor untuk membeli saham perusahan yang beresar berdasarkan harga yang telah ditentukan oleh investor. Apabila harga yang dibayarkan investor tinggi maka dapat dikatakan nilai perusahaan tinggi.

Pada penelitian ini nilai perusahaan dihitung dengan menggunakan rasio price to book value (PBV). PBV adalah suatu rasio yang menunjukkan hubungan antara harga pasar saham perusahaan dengan nilai buku perusahaan. Dengan rasio ini investor dapat mengetahui beberapa kelipatan harga pasar terhadap nilai buku per lembar saham yang menjadi investasinya. Rasio PBV dapat mengukur nilai yang diberikan pasar keuangan, manajemen, dan organisasi perusahaan sebagai sebuah perusahaan yang terus tumbuh (Bringham, 2001). Rasio PBV dapat memperlihatkan besarnya penilaian publik terhadap harga buku/nilai perusahaan persaham yang tercermin dalam pasar di bursa atau pasar modal. Semakin besar nilai PBV maka semakin tinggi apresiasi investor terhadap nilai perusahaan.

\section{Intellectual Capital}

Secara umum intellectual capital didefinisikan sebagai perbedaan antara nilai pasar perusahaan dan nilai buku dari aset perusahaan tersebut atau dari financial capital. Menurut (Ulum, 2009) dalam penelitiannya mengindikasikan intellectual capital sebagai nilai yang tersembunyi (hidden value) dari bisnis, yang menghubungkan dua hal yaitu tidak terlihat secara umum layaknya aset tradisional dan tidak terlihat ada dalam laporan keuangan. Intellectual capital meliputi teknologi informasi pelanggan, brand name, reputasi, budaya organisasi yang tidak ternilai bagi kekuatan kompetitif perusahaan.

Berbagai penelitian tentang intellectual capital melahirkan banyak definisi yang beragam dari para peneliti. Bontis (2000) dalam Goh (2005) mendefinisikan intellectual capital sebagai seluruh pengetahuan karyawan dan perusahaan yang berkontribusi bagi keunggulan kompetitif perusahaan yang berkelanjutan. Pulic (2001) dalam Nofitasari (2009) mendefinisikan intellectual capital sebagai seluruh karyawan, perusahaan dan kemampuan mereka untuk menciptakan nilai tambah bagi perusahaan. Modal intellectual sebagai aset yang tidak berwujud yang merupakan sumberdaya berisi pengetahuan yang dapat mempengaruhi kinerja suatu perusahaan baik dalam pembuatan keputusan untuk saat ini maupun manfaat dimasa datang.

Berdasarkan pengertian yang dikemukakan oleh para ahli maka intellectual capital dapat didefinisikan sebagai jumlah dari apa yang dihasilkan oleh tiga elemen utama organisasi (human capital, structur capital, costumer capital) yang berkaitan dengan pengetahuan dan teknologi yang dapat memberikan nilai lebih bagi perusahaan berupa keunggulan bersaing organisasi. Pada umumnya para peneliti membagi intellectual capital menjadi tiga komponen, yaitu human capital (HC), structural capital (SC), dan customer capital (CC). Secara sederhana HC mencerminkan individual knowledge stock suatu organisasi yang dipresentasikan oleh karyawannya. HC ini termasuk kompetensi, komitmen, dan loyalitas karyawan terhadap perusahaan. SC meliputi seluruh non-human storehouses of knowledge dalam organisasi. 
Termasuk dalam SC adalah database, organizational chart, process manual, strategies, routines, dan segala hal yang membuat nilai perusahaan lebih besar dari nilai materialnya. Sedangkan CC adalah pengetahuan yang melekat dalam marketing channels dan customer relationship (Bontis 2001 dalam Ulum et al 2008).

Pengukuran Intellectual capital pada penelitian ini merujuk pada pengukuran Value Added Intellectual Capital Coeffisient (VAIC ${ }^{\mathrm{TM}}$ ) yang dikembangkan oleh Pulic (1998) yang kemudian dimodifikasi oleh Ulum (2014) menjadi Modified Value Added Intellectual Coefficient (MVAIC). Metode ini muncul berdasarkan penelitian Brinker (1998), Steward (1997), dan Draper (1998) dalam Ulum (2014) yang menyatakan bahwa intellectual capital terdiri dari tiga komponen yakni, human capital (HC), structural capital (SC), dan relational capital (RC). Penambahan satu komponen berupa relational capital efficiency (RCE) ini menegaskan bahwa dalam perhitungan VAIC menggunakan dua komponen modal yaitu CEE (Capital employed efficiency) dan ICE (Intellectual Capital Efficiency) yang merupakan penambahan dari HCE, SCE, RCE.

\section{Profitabilitas}

Profitabilitas adalah kemampuan perusahaan menghasilkan keuntungan pada tingkat penjualan, aset dan modal saham yang tertentu. Menurut Bringham (2001), profitabilitas adalah hasil akhir dari serangkaian kebijakan dan keputusan manajemen, dimana kebijakan dan keputusan ini menyangkut pada sumber dan penggunaan dana dalam menjalankan operasional perusahaan yang tercantum dalam laporan posisi keuangan. Rasio keuangan profitabilitas sangat diperlukan oleh investor dalam jangka panjang untuk menganalisis keuntungan yang akan diterima dalam bentuk deviden (Saleh, 2008). Tingkat keuntungan dipakai sebagai salah satu cara untuk menilai keberhasilan efektifitas perusahaan, berkaitan dengan hasil akhir dari berbagai kebijakan dan keputusan perusahaan yang telah dilaksanakan oleh perusahaan dalam periode berjalan (Saleh, 2008).

Menurut Hardiyanti (2012) profitabilitas adalah tingkat keuntungan bersih yang diperoleh oleh perusahaan pada saat menjalankan kegiatannya.Profitabilitas adalah kemampuan perusahaan dalam meningkatkan atau mendapatkan laba selama periode tertentu. Profitabilitas yang tinggi akan mencerminkan prospek perusahaan yang baik, semakin baik prospek perusahaan maka semakin meningkat pula nilai perusahaan.

Perusahaan menggunakan profitabilitas untuk mengevaluasi pengelolaan badan usahanya apakah efisien dan efektif. Perbandingan antara laba yang diperoleh dengan aktiva atau modal yang digunakan untuk menghasilan laba adalah sebagai acuan mengukur seberapa besar laba yang diraih kemudian baru dapat dikatakan pengelolaannya efisien atau belum. Adanya kemampuan memperoleh laba dengan sumber daya yang dimiliki perusahaan maka tujuan-tujuan perusahaan akan dapat tercapai.

Profitabilitas dalam penelitian ini diukur dengan menggunakan rasio ROE (Return On Equity). Menurut Brigham dan Houston (2001) Return on Equity (ROE) adalah rasio laba bersih setelah pajak terhadap modal sendiri. Rasio ini dapat mengukur tingkat pengembalian atas investasi yang telah dilakukan. Semakin tinggi ROE semakin baik juga kedudukan pemilik perusahaan, sehingga menyebabkan baiknya penilaian investor terhadap perusahaan yang dapat meningkatkan harga saham dan nilai perusahaan. 


\section{Hubungan antara Intellectual Capital dan Nilai Perusahaan}

Teori stakeholder menyatakan bahwa perusahaan bukanlah entitas yang hanya beroperasi untuk kepentingannya sendiri namun harus memberikan manfaat bagi stakeholder (Ulum dkk. 2008). Sumber daya yang dikelola dengan maksimal dapat meningkatkan nilai perusahaan yang kemudian akan meningkatkan laba perusahaan dan dapat menghasilkan keuntugan bagi para pemegang saham. Para investor di pasar modal akan menunjukkan apresiasi atas keunggulan intellectual capital yang dimiliki oleh perusahaan dengan berinvestasi pada perusahaan, sehingga akan berdampak pada naiknya nilai perusahaan. Peningkatan nilai perusahaan berbanding lurus dengan pemanfaatan intellectual capital, jika kinerja dan capaian intellectual capital meningkat maka nilai perusahaan juga akan meningkat.

Randa dan Solon (2012) menguji pengaruh intellectual capital terhadap nilai perusahaan. Hasilnya, menyatakan bahwa intellectual capital berpengaruh positif terhadap nilai perusahaan dalam konteks perusahaan manufaktur yang terdaftar pada Bursa Efek Indonesia (BEI). Penelitian Solikhah (2010) menunjukkan adanya pengaruh positif signifikan antara intellectual capital terhadap nilai perusahaan yang diproksikan dengan PBV (Price to Book Value ). Chen (2005) menyatakan bahwa intellectual capital mempunyai pengaruh positif terhadap nilai perusahaan. Berdasarkan penjelasan dan uraian diatas peneliti merumuskan hipotesis kedua sebagai berikut:

H1: Intellectual capital berpengaruh positif terhadap nilai perusahaan.

\section{Hubugan antara Intellectual Capital dengan Nilai Perusahaan melalui Profitabilitas}

Teori berbasis sumber daya (RBT) memberikan asumsi dimana perusahaan dapat bersaing secara kompetitif apabila perusahaan tersebut dapat mengelola dan menggunakan sumber daya sesuai dengan kemampuan yang dimilikinya Pemanfaatan sumber daya yang dimiliki oleh perusahaan hendaknya didukung oleh kemampuan intelektual perusahaan yang baik pula. Jika intellectual capital merupakan sumber daya yang terukur untuk peningkatan keunggulan kompetitif, maka intellectual capital akan memberikan kontribusi terhadap kinerja keuangan serta meningkatkan nilai perusahaan.

Penelitian sebelumnya yang dilakukan oleh Belkaoui (2003), wicaksana (2011), Chen et al. (2005), Tan et al. (2007), Yunita (2012) dan Rubhyanti (2008) menunjukkan bahwa modal intelektual berpengaruh positif terhadap kinerja dan nilai pasar perusahaan. Sedangkan penelitian Solikhah dkk.(2010), Sunarsih dan Mendra (2012) serta Yuniasih dkk.(2010) tidak berhasil membuktikan bahwa modal intelektual berpengaruh pada nilai perusahaan.Penelitian ini menambahkan variabel intervening (profitabilitas) untuk memediasi intellectual capital dengan nilai perusahaan. Berdasarkan teori dan diperkuat dengan hasil penelitian tersebut maka hipotesis keempat yang diajukan dalam penelitian ini adalah :

H2: Intellectual capital berpengaruh positif terhadap nilai perusahaan melalui profitabilitas

\section{METODOLOGI PENELITIAN}

\section{Jenis Penelitian}

Penelitian ini menggunakan pendekatan kuantitatif dengan jenis penelitian kausal komparatif, dan penelitian ini menggunakan data sekunder yang dikumpulkan dengan metode purposive sampling. Subjek penelitian ini adalah perusahaan sektor keuangan yang terdaftar di Bursa Efek Indonesia (BEI) tahun 2013 sampai 2017. Penelitian ini menggunakan total sampling dengan jumlah sampel sebanyak 51 perusahaan sektor keuangan. 


\section{Teknik Pengumpulan Data}

Pengumpulan data adalah prosedur yang sistematis dan standar untuk memperoleh data yang diperlukan (Nazir, 2009). Teknik pengumpulan data dalam penelitian ini adalah teknik observasi dokumentasi dengan mengumpulkan, melihat dan mengelola data laporan keuangan dan laporan tahunan perusahaan keuangan pada tahun 2013-2017.

\section{Pengukuran Variabel}

Nilai Perusahaan (Y)

Variabel nilai perusahaan dihitung dengan mengguanakan rasio price book value (PBV).

$$
\text { PBV } \frac{\text { harga saham }}{\text { Nilai buku saham }}
$$

\section{Intellectual Capital $(\mathbf{X})$}

Variabel intellectual capital diukur dengan mengguanakan Modified Value Added Intellectual Capital Coefficient (MVAIC), yang terdiri dari tiga komponen pembentuk intellectual capital efficiency (ICE) yaitu human capital, structural capital, relational capital yang kemudian ditambahkan dengan komponen capital employed efficiency (CEE).

$$
\begin{gathered}
\mathrm{MVAIC}=(\mathrm{HCE}+\mathrm{SCE}+\mathrm{RCE})+\mathrm{CEE} \\
\mathrm{MVAIC}=\mathrm{ICE}+\mathrm{CEE}
\end{gathered}
$$

\section{Profitabilitas (Z)}

Profitabilitas sebagai variabel mediasi yang memberikan pengaruh tidak langsung terhadap variabel eksogen terhadap variabel endogen. Profitabilitas diukur dengan manggunakan rasio return on equity (ROE).

$$
R O E=\frac{\text { laba bersih }}{\text { ekuitas }}
$$

\section{Teknik Analisis Data}

Analisis data dalam penelitian ini menggunakan pendekatakan Partial Least Square (PLS).

\section{Model Pengukuran (Outer Model)}

Uji Outer Model menggunakan dua indikator yaitu indikator Reliability \& Internal Consistency Reliability dan Convergent Validity \& Discriminant Validity.

\section{Model Struktural (Inner Model)}

Ada 4 uji untuk inner modal yaitu : Koefisien Determinan $\left(\mathrm{R}^{2}\right), \mathrm{F}^{2}$ untuk Effect Size, Prediction relevance $\left(\mathrm{Q}^{2}\right)$, Path Coefficient (Uji Hipotesis).

\section{HASIL DAN PEMBAHASAN}

\section{Hasil Uji Outer Model}

Model pengukuran (outer model) melihat antara indikator dengan variabel latennya. Model pengukuran terdiri atas dua yaitu untuk indikator reflektif dan indikator formatif, adapun model pengukuran untuk uji validitas dan reliabilitas dapat dilihat pada gambar 4.1 sebagai berikut: 


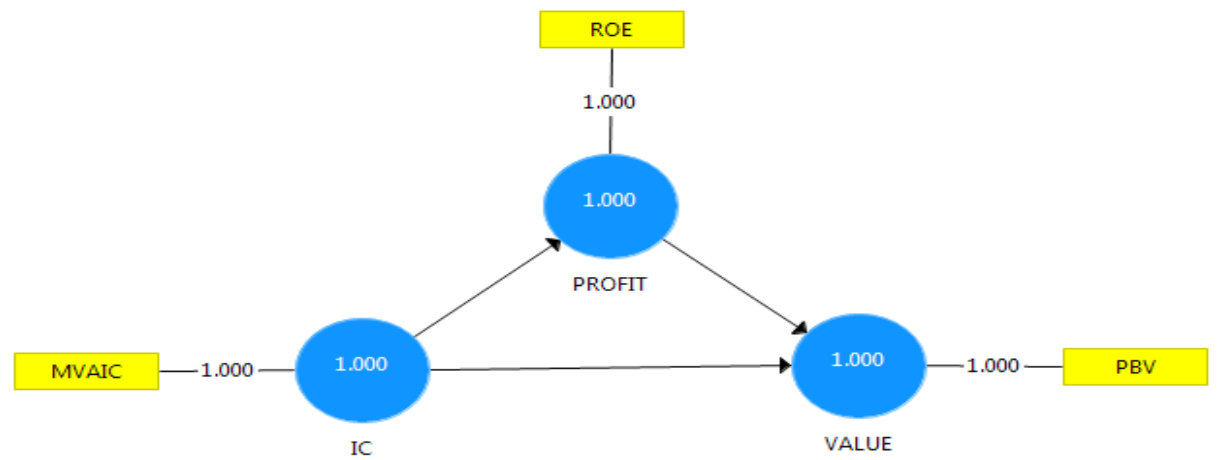

Gambar 1 Tampilan PLS Algorithm

Sumber : Olahan penulis menggunakan software Smart PLS ver 3.2.7

Uji Indicator Reliability \& Internal Consistency

Pengujian reliabilitas digunakan untuk melihat apakah data dalam penelitian konsisten atau tidak. Konstruk dalam penelitian dinyatakan reliabel jika memiliki nilai composite reliability di atas 0,70 dan cronbach's alpha diatas 0,60 .

Tabel 1

Composite Reliability dan Cronbach Alpha

\begin{tabular}{|c|c|c|}
\hline Konstruk & Composite Reliability & Cronbach Alpha \\
\hline IC & 1.000 & 1.000 \\
\hline PROFIT & 1.000 & 1.000 \\
\hline VALUE & 1.000 & 1.000 \\
\hline
\end{tabular}

Sumber : Olahan penulis menggunakan software Smart PLS ver 3.2.7

Berdasarkan tabel diatas diketahui bahwa semua konstruk memiliki nilai composite reliability di atas 0,70 dan cronbach's alpha diatas 0,60. Sehingga dapat disimpulkan bahwa konstruk memiliki reliabilitas yang baik.

\section{Uji Convergent Validity \& Discriminant Validity}

Validitas konvergen dari model pengukuran dengan menggunakan indikator reflektif dinilai berdasarkan nilai indikator-indikator yang mengukur konstruk. Uji validitas konvergen dilakukan dengan melihat nilai Average Variance Extracted (AVE). Nilai AVE yang di isyaratkan minimal 0,5. Berikut hasil olah data AVE;

Tabel 2

Average Variance Extracted (AVE)

\begin{tabular}{|c|c|}
\hline Konstruk & AVE \\
\hline IC & 1.000 \\
\hline PROFIT & 1.000 \\
\hline VALUE & 1.000 \\
\hline
\end{tabular}

Sumber : Olahan penulis menggunakan software Smart PLS ver 3.2.7 
Pengujian discriminat validity dilakukan untuk membuktikan apakah indikator pada suatu konstruk akan mempunyai fornell larcker criterion terbesar pada konstruk yang dibentuk dari fornell larcker criterion dengan konstruk yang lain. Berikut uji discriminant validity menggunakan software SmartPLS yaitu :

\section{Tabel 3}

\section{Discriminant Validity}

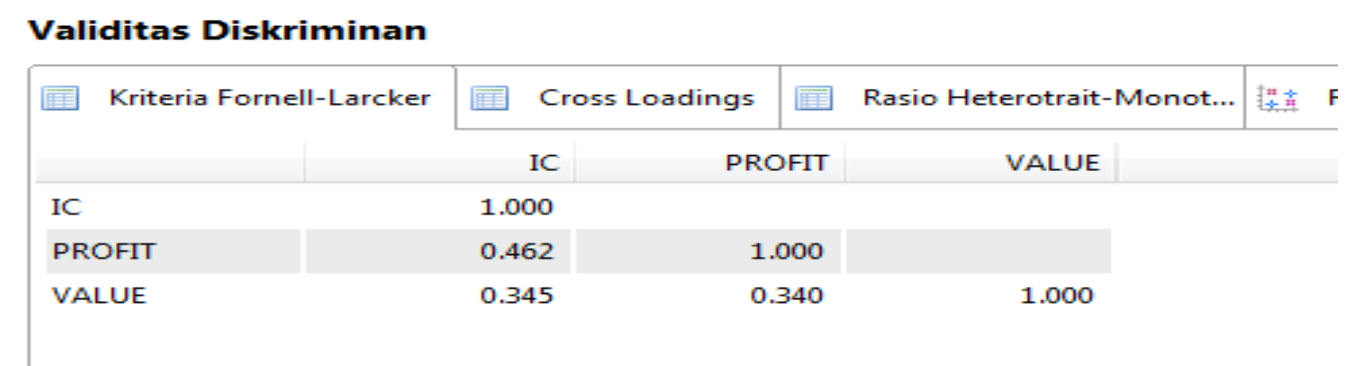

Sumber : Olahan penulis menggunakan software Smart PLS ver 3.2.7

Berdasarkan output diatas terlihat bahwa nilai terendah sebesar 0.325 dan tertinggi 1.000. Selain uji indikator reflektif diatas juga terdapat uji indikator formatif. Uji ini digunakan untuk melihat hubungan kausalitas dari indikator ke variabel laten maupun antar indikator. Uji indikator formatif dilihat nilai multicollinearity pada output Smart PLS. Kriteria jika nilai VIF antara 5-10 maka indikator terjadi multikolinearitas. Berikut output multicollinearity:

Tabel 4

Multicollinearity

\begin{tabular}{|c|c|}
\hline Proksi & VIF \\
\hline MVAIC & 1.000 \\
\hline PBV & 1.000 \\
\hline ROE & 1.000 \\
\hline
\end{tabular}

Sumber : Olahan data menggunakan software Smart PLS versi 3.2.7

Berdasarkan output diatas terlihat bahwa semua indikator yang digunakan memiliki VIF 1.000 hal ini bermakna indikator dalam penelitian terbebas dari masalah multikolinearitas.

\section{Pengujian Model Struktural (Inner Model)}

Pengujian inner model digunakan untuk melihat hubungan antar variabel laten. Inner model dilihat dari output $\mathrm{R}^{2}, \mathrm{~F}^{2}, \mathrm{Q}^{2}$ dan path coefficient. Berikut tampilan path coefficient, yaitu:

\section{Koefisien Determinasi $\left(\mathbf{R}^{2}\right)$}

Koefisien determinasi digunakan untuk melihat kemampuan variabel eksogen menjelaskan variabel endogen dalam penelitian. Pada penelitian ini menggunakan output R-square dalam melakukan analisis data. Berikut hasil olahan data koefisien determinasi, yaitu: 


\section{Tabel 5}

\section{Koefisien Determinasi}

\section{R Square}

\begin{tabular}{|c|c|c|c|c|}
\hline \multirow[t]{2}{*}{ Matriks } & 接章 & R Square & 措高 $\mathrm{A}$ & justed R Square \\
\hline & & \multicolumn{2}{|c|}{ R Square } & Adjusted R Sq... \\
\hline PROFIT & & & 0.213 & 0.197 \\
\hline VALUE & & & 0.161 & 0.126 \\
\hline
\end{tabular}

Sumber : Olahan data menggunakan software Smart PLS versi 3.2.7

Berdasarkan tabel diatas menunjukkan nilai R-square 0.213 untuk konstruk PROFIT yang berarti bahwa IC mampu menjelaskan varian PROFIT sebesar 21.3\%. nilai R-square juga terdapat pada VALUE yang dipengaruhi oleh IC dan PROFIT sebesar 0.161 yang berarti IC dan PROFIT mampu menjelaskan VALUE sebesar $16.1 \%$.

\section{Effect Size $\left(\mathbf{F}^{2}\right)$}

Nilai Effect Size $\left(\mathrm{F}^{2}\right)$ digunakan untuk melihat kelebihan model penelitian. Berikut tabel hasil olahan peneliti untuk uji $\mathrm{F}^{2}$, yaitu :

Tabel 6

Effect Size $\left(\mathbf{F}^{2}\right)$

\begin{tabular}{|c|c|c|c|}
\hline & IC & PROFIT & VALUE \\
\hline IC & & 0.271 & 0.054 \\
\hline PROFIT & & & 0.049 \\
\hline VALUE & & & \\
\hline
\end{tabular}

Sumber : Olahan data menggunakan software Smart PLS versi 3.2.7

Berdasarkan tabel diatas menunjukkan bahwa nilai effect size terendah sebesar 0.45 sedangkan nilai effect size tertinggi sebesar 0.269 .

\section{Prediction Relevance $\left(\mathbf{Q}^{2}\right)$}

Uji ini dilakukan untuk mengetahui kapabilitas prediksi variabel eksogen terhadap variabel endogen didalam penelitian menggunakan prosedur blindfolding. Berikut output uji prediction relevance, yaitu: 


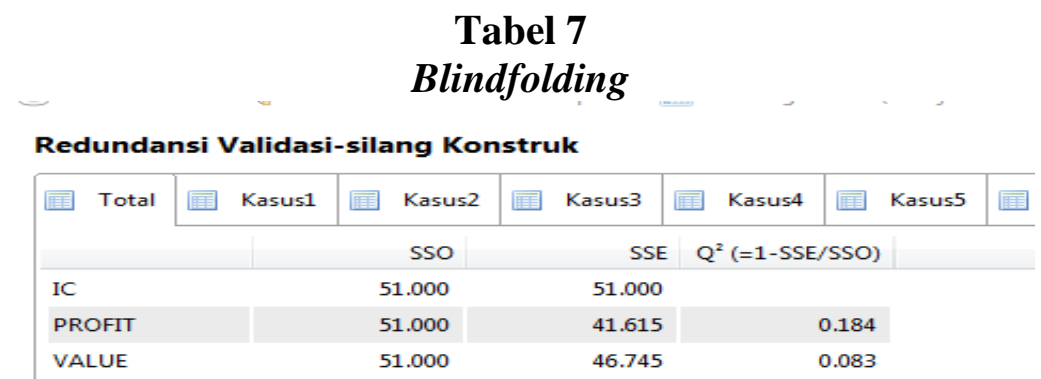

Sumber : Olahan penulis menggunakan software Smart PLS versi 3.2.7

Berdasarkan tabel diatas terlihat kapabilitas prediksi intellectual capital terhadap nilai perusahaan melalui profitabilitas adalah 0.184 sesuai kriteria yang ada maka intellectual capital terhadap nilai perusahaan melalui profitabilitas masuk dalam kategori "kapabilitas prediksi sedang". Sedangkan kapabilitas prediksi intellectual capital terhadap nilai perusahaan adalah 0.83. Hasil ini bermakna kapabilitas prediksi intellectual capital terhadap nilai perusahaan masuk kategori "kapabilitas prediksi kecil"

\section{Path Coefficient (Uji Hipotesis)}

Kriteria pengaruh hubungan variabel dinyatakan diterima jika nilai T-statistic lebih besar dari pada T-table. Nilai t-table untuk hipotesis dua ekor (two-tailed) dan >1.64 untuk hipotesis satu ekor (one-tailed). Sedangkan untuk melihat arah hubungan hipotesis digunakan nilai original sample, jika nilai original sampel positif berarti arah hubungan hipotesis positif, sedangkan jika nilai original sampel negatif maka arah hubungan hipotesisnya negatif (Abdillah et al. 2015). Berikut ringkasan nilai t-statistic dan original sample untuk pengaruh langsung (direct effect) dan pengaruh tidak langsung (indirect effect) sebagai berikut :

\section{Tabel 8}

Uji Hipotesis

\begin{tabular}{|c|c|c|c|c|}
\hline $\begin{array}{c}\text { Hubungan } \\
\text { Variabel }\end{array}$ & T-statistic & $\begin{array}{c}\text { Original } \\
\text { Sample }\end{array}$ & $\begin{array}{c}\text { Arah } \\
\text { Hubungan }\end{array}$ & Keputusan \\
\hline IC-VALUE & 2.741 & 0.345 & positif & Diterima \\
\hline IC-PROFIT-VALUE & 1.154 & 0.106 & positif & Ditolak \\
\hline
\end{tabular}

Sumber : Olahan penulis menggunakan software SmartPLS versi 3.2.7

\section{Pengujian Hipotesis 1}

Berdasarkan table 8 di atas, dapat disimpulkan bahwa hipotesis pertama terdukung karena nilai $t$ statistic untuk pengaruh intellectual capital terhadap nilai perusahaan sebesar 2.741 di atas nilai t-table. Arah hubungan langsung intellectual capital terhadap nilai perusahaan adalah positif karena nilai original sample yang diperoleh bernilai positif sebesar 0.327. Sehingga diperoleh kesimpulan bahwa intellectual capital berpengaruh positif terhadap nilai perusahaan. Berarti hipotesis pertama diterima.

\section{Pengujian Hipotesis 2}

Berdasarkan table 8 di atas, dapat disimpulkan bahwa hipotesis kedua tidak terdeukung karena nilai $t$-statistic untuk pengujian pengaruh tidak langsung intellectual capital terhadap nilai perusahaan melalui profitabilitas diperoleh sebesar 1.154 dibawah nilai t-table. Arah hubungan 
pengaruh intellectual capital terhadap nilai perusahaan melalui profitabilitas adalah positif karena nilai original sample yang diperoleh bernilai positif (1.106). Sehingga diperoleh kesimpulan bahwa profitabilitas tidak terbukti menjadi mediasi hubungan intellectual capital dengan nilai perusahaan. Berarti hipotesis kedua ditolak.

\section{Pembahasan}

\section{Pengaruh Intellectual Capital terhadap Nilai perusahaan}

Penelitian ini membuktikan bahwa variabel intellectual capital berpengaruh signifikan positif terhadap nilai perusahaan yang di ukur dengan price to book value (PBV). Hal ini menunjukkan bahwa pengelolaan intellectual capital secara maksimal terbukti mampu meningkatkan nilai perusahaan. Hasil ini sesuai dengan teori stakeholder yang menyatakan bahwa investor cenderung akan memberikan apresiasi lebih terhadap perusahaan yang mampu mengelola intellectual capital dengan baik. Temuan ini mengindikasikan bahwa perusahaan tersebut mampu menciptakan nilai tambah (value added) dan secara tidak langsung akan meningkatkan kesejahteraan para stakeholder.

Hasil penelitian ini mendukung teori berbasis sumber daya atau Resource Based Theory (RBT) yang membahas mengenai sumber daya yang dimiliki perusahaan, dan bagaimana perusahaan dapat mengembangkan keunggulan kompetitif dari sumber daya yang dimilikinya. Pengelolaan sumber daya agar dapat menonjolkan keunggulan pengetahuan (knowledge/learning economic) sehingga dapat mengandalkan aset-aset tak berjuwud yang dimiliki agar dapat bersaing dan melebihi para kompetitornya. Selain itu resource based theory (RBT) yang berfokus pada sumber daya dan pengelolaan organisasi yang pada akhirnya mengarahkan pada penciptaan nilai perusahaan.

Perusahaan yang dapat mengelola dan memanfaatkan intellectual capital baik itu modal untuk tenaga kerja (HC), struktur perusahaan (SC), kegiatan pemasaran (RC), dan modal yang dimiliki perusahan (CE) secara efektif dan efisien akan meningkatkan kinerja keuangan perusahaan dan akan mendapatkan respon yang positif dari pihak stakeholder yakni investor melalui fluktuasi harga saham perusahaan.

Berdasarkan hasil penelitian ini juga dapat diambil kesimpulan bahwa, perusahaan sektor keuangan di Indonesia telah berbasis pada knowladge intensive high tech firms dalam membangun bisnisnya. Perusahaan sektor keuangan juga telah memberikan perhatian terhadap human capital, struktural capital, custumer capital sebagai komponen dari intellectual capital. Perusahaan yang berbasis pada pengetahuan kemakmuran suatu perusahaan akan sangat bergantung pada suatu penciptaan transformasi dan kapitalisasi dari pengetahuan itu sendiri. Pengelolan intellectual capital secara efisien dan ekonomis akan memberikan keunggulan bersaing.

Hasil penelitian ini selaras dengan penelitian dari (Berzkalne \& Zelgave (2014), Chizari et al, (2016), Suparno \&Ramadini (2017), Hariyati et al, (2017) yang memberikan arti bahwa intellectual capital berpengaruh terhadap nilai perusahaan, karena saat ini untuk meningkatkan nilai perusahaan tidak hanya tergantung pada modal fisik saja melainkan modal intelektual yang dimiliki. Hasil penelitian ini berbeda dengan penelitian yang dilakukan oleh Solikhah et al. (2010), Yuniasih et al. (2010), mehralian et al. (2012), Sunarsih dan Mendra (2012), Faza dan Hidayah (2014), yang menyatakan bahwa penghargaan pasar pada suatu perusahaan lebih didasarkan pada sumber daya fisik yang dimiliki perusahaan tersebut, dan investor cenderung tidak menitikberatkan pada sumber daya intellectual yang dimiliki. 


\section{Pengaruh Intellectual Capital terhadap Nilai Perusahaan melalui Profitabitas}

Penelitian ini menunjukan bahwa variabel profitabilitas yang diukur dengan return on equity (ROE) tidak terbukti memediasi hubungan intellectual capital dengan nilai perusahaan yang di ukur dengan price to book value (PBV). Hipotesis ke 2 bermakna semakin besar intellectual capital maka semakin besar nilai perusahaan melalui profitabilitas yang diukur dengan ROE. Namun, hasil penelitian tidak mampu membuktikan dugaan peneliti mengenai adanya pengaruh profitabilitas yang memediasi hubungan intellectual capital dengan nilai perusahaan.

Tata kelola dan pemanfaatan intellectual capital yang baik, yang mampu bersaing dan kemudian akan meningkatkan kinerja keuangan salah satunya adalah profitabilitas. Kontribusi profitabilitas yang diproksikan dengan ROE sebagai dampak penerapan intellectual capital yang baik ternyata tidak terbukti meningkatkan nilai perusahaan dimata investor. Sehingga profitabilitas sebagai variabel mediasi pada penelitian ini tidak dapat memperkuat hubungan antara intellectual capital dengan nilai perusahaan. Sejalan dengan hasil penelitian yang dilakukan Wibowo (2016) yang tidak berhasil membuktikan profitabilitas gagal memediasi hubungan intellectual capital dengan nilai perusahan.

Hal ini tidak sejalan dengan hasil penelitian yang dilakukan oleh Sunarsih dan Mendra (2012) dan Hadiwijaya (2013). Penelitian Sunarsih dan Mendra (2012) mengindikasikan bahwa kinerja keuangan yang di ukur dengan ROE sebagai variabel intervening mampu memediasi hubungan antara intellectual capital dan nilai perusahaan. Temuan penelitian Sunarsih dan Mendra (2012) menunjukkan bahwa pasar memberikan penilaian yang lebih tinggi kepada perusahaan yang memiliki kinerja keuangan yang tinggi. Kinerja keuangan dapat meningkat karena perusahaan mampu mengelola sumbar daya intelektualnya dengan efektif dan efisien.

Intellectual capital diyakini dapat berperan penting dalam peningkatan nilai perusahaan maupun kinerja keuangan. Resource based theory menyatakan bahwa kemampuan perusahaan dalam mengelola sumber dayanya dengan baik dapat menciptakan keunggulan kompetitif sehingga dapat menciptakan nilai bagi perusahaan. Perusahaan yang mampu memanfatkan intellectual capital secara efisien, maka nilai pasarnya akan meningkat (Sunarsih dan Mendra, 2012).

Tujuan utama dari teori stakeholder adalah untuk membantu manajemen perusahaan dalam meningkatkan penciptaan nilai sebagai dampak dari aktivitas-aktivitas yang dilakukan dan meminimalkan kerugian yang mungkin muncul bagi pihak stakeholder. Sehingga pengguanaan semua potensi yang dimiliki oleh perusahan baik aktiva berwujud maupun tidak berwujud harus dimanfaatkan dengan baik yang pada kahirnya akan meningkatkan nilai dari perusahaan. Kepemilikan serta pemanfaatan sumber daya intelektual memungkinkan perusahaan mencapai keunggulan bersain dan nilai tambah. Investor akan meberikan penghargaan lebih kepada perusahaan yang mampu menciptakan nilai tambah secara berkesinambungan dalam hal ini adalah pemanfaatan intellectual capital oleh perusahaan.

Pengelolaan sumber daya yang maksimal dapat meningkatkan nilai perusahaan yang kemudian akan meningkatkan laba perusahaan sekaligus menghasilkan keuntungan bagi para pemegang saham. Pasar akan memberikan penilaian yang lebih tinggi kepada perusahaan yang memiliki modal intelektual tinggi, sehingga diharapkan dengan pengelolaan yang baik terhadap modal intelektual tersebut dapat meningkatkan nilai perusahaan yang merupakan orientasi dari para stakeholder dalam mengintervensi manajemen perusahaan (Fitriyani dan Amalia, 2018). 


\section{SIMPULAN, KETERBATASAN, DAN SARAN \\ Kesimpulan}

Hasil penelitian dan pengujian hipotesis ini telah dilakukan, maka hasil penelitian dapat disimpulkan sebagai berikut:

a. Intellectual capital berpengaruh positif terhadap nilai perusahaan sektor keuangan di BEI tahun 2013-2017. Pengelolaan intellectual capital secara maksimal terbukti mampu meningkatkan nilai perusaan. Investor cenderung akan memberikan apresiasi lebih terhadap perusahaan yang mampu mengelola intellectual capital dengan baik. Temuan ini mengindikasikan bahwa perusahaan tersebut mampu menciptakan nilai tambah (value added) dan secara tidak langsung akan meningkatkan kesejahteraan para stakeholder.

b. Profitabilitas tidak terbukti menjadi mediasi hubungan intellectual capital dan nilai perusahaan pada perusahaan sektor keuangan di BEI tahun 2013-2017. Hasil penelitian tidak mampu membuktikan dugaan peneliti mengenai adanya pengaruh profitabilitas yang memediasi hubungan intellectual capital dengan nilai perusahaan.

\section{Keterbatasan}

Penelitian ini memiliki keterbatasan yaitu sebagai berikut:

a. Variabel mediasi yaitu profitabilitas yang diukur dengan rasio (ROE) tidak mampu memediasi variabel intellectual capital dengan nilai perusahaan. Dikarenakan bahwa nilai t-statisticnya tidak mencapai angka >1.64, sehingga kegunaan persepsian memediasi penuh (fully mediating) yang diharapkan tidak tercapai.

b. Masih ada sejumlah variabel lain yang belum digunakan dalam penelitian ini sedangkan variabel tersebut memiliki pengaruh terhadap nilai perusahan

\section{Saran}

a. Peneliti selanjutnya dapat menggunakan perusahaan selain sektor keuangan yang dijadikan sampel penelitian. Misalnya sektor manufaktur, sektor property, real estate, dan konstruksi dan bangunan.

b. Peneliti selanjutanya dapat menggunakan variabel lain dalam memediasi hubungan intellectual capital dengan nilai perusahaan.

c. Penelitian selanjutnya diharapkan dapat menggunakan proksi lain dalam mengukur setiap variabel yang diteliti.

\section{DAFTAR PUSTAKA}

Abdillah, W., dan J. Hartono. 2015. Partial Least Square (PLS). Yogyakarta: Penerbit Andi Agustina, Silvia. 2013. Pengaruh Profitabilitas dan penggungkapan CSR Terhadap Nilai Perusahan (Studi empiris pada perusahaan Manufaktur yang terdaftar di BEI). Skripsi: Universitas Negeri Padang.

Ahmadi, Nugroho. 2012. Faktor- Faktor yang Mempengaruhi Intellectul Capital Disclousure. Accounting Analysis journal.1(2)

Atmaja, Lukas Setia. 2008. Manajemen Keuangan. Yogyakarta: Andi.

Brigham, Eugene dan Houston Joel. 2001. Manajemen Keuangan. Jakarta: Erlangga.

Chen, M-C, Cheng Shu-Ju and Hwang Y. 2005. "An Empirical Investigation of the Relationship Between Intellectual Capital and Firm's Market Value and Financial Performance." Journal of Intellectual Capital Vol. 6 No. 2 page 159-170 
Deegan, C. 2004. Financial Accounting Theory. McGraw-Hill Book Company. Sydney.

Firer, S., and S.M. Williams. 2003. Intellectual Capital and Traditional Measures of Corporate Performance. Journal of Intellectual Capital 4 (3) : 348- 360.

Ghozali, Imam. 2011. Structural Equation Modelling: Metode Alternatif dengan Partial Least Square. Semarang: Badan Penerbit Universitas Diponegoro.

Goh, P. (2005), Intellectual capital performance of commercial banks in Malaysia. Journal of Intellectual Capital Vol.6.No.3 hal.385-396.

Hardiyanti, Nia. 2012. Analisis Pengaruh Insider Ownership, Leverage, Profitabilitas, Firm Size, dan Dividend Payout Ratio terhadap Nilai Perusahaan. Skripsi

Harmono. (2011). Manajemen Keuangan (Berbasis Balance Scorecard Pendekatan Teori, Kasus, dan Riset Bisnis). Jakarta: Bumi Aksara.

Hermawan Kartajaya.2010. Brand Operation The Official MIM Academy Course book. Jakarta: Esesnsi Erlangga Group.

Hermuningsih, Sri. 2013. Pengaruh Profitabilitas, Growth Opportunity, Struktur Modal Terhadap Nilai Perusahaan Pada Perusahaan Publik di Indonesia. Buletin Ekonomi Moneter dan Perbankan, Oktober, pp. 127-148.

Ikatan Akuntan Indonesia. 2002. Pernyataan Standar Akuntansi Keuangan. No.19. Salemba Empat. Jakarta.

Nazir, Moh. Ph. D. 2009. Metode Penelitian. Jakarta: Ghalia Indonesia

Novitasari, Tera. 2009. Pengaruh Struktur Kepemilikan Terhadap Kinerja Intellectual Capital.

Pulic, 1998. Measuring the Performance of intellectual potential in knowledge economy. Paper presented at the 2nd McMaster Word Congress on Measuring and Managing Intellectual Capital.

Randa, F., \& Solon, S. A. 2012. Pengaruh modal intelektual terhadap nilai perusahaan. Jurnal sistem informasi manajemen dan akuntansi, 24-47.

Saleh, Norman Mohd 2008. Ownership structure and intellectual capital performance in Malaysia. http://www.ssrn.com diakses 25 November 2018.

Solikhah, Badingatus. 2010. Implikasi Intellectual Capital Terhadap Financial Performance, Growth Dan Market Value; Studi Empiris Dengan Pendekatan Simplistic Specification. Simposium Nasional Akuntansi XIII.

Subkhan, Dyah Pitaloka Citranigrum. 2010. Pengaruh Intellectual Capital terhadap Kinerja Keuangan Perusahaan Perbankan Periode 2005-2007. Jurnal Dinamika Akuntansi, Vol.2, No. 1, Maret 2010, 30-36.

Yuniasih,N W., D. G. Wirama, dan I. D. N. Badera. 2010. Eksplorasi Kinerja Pasar Perusahaan: Kajian Berdasarkan Modal Intelektual (Studi Empiris pada Perusahaan Keuangan yang Terdaftar di Bursa Efek Indonesia). Simposium Nasional Akuntansi XIII, Purwokerto.

Ulum, I., I. Ghozali., dan A. Chariri. 2008. Intellectual Capital dan Kinerja Keuangan Perusahaan: Suatu Analisis dengan pendekatan Partial Leas Squares. Simposium Nasional akuntansi (SNA) Ke XI. Universitas Tanjung Pura.

Ulum, I. Ghozali., dan A. Purwanto. 2014. Intellectual Capital Performance of Indonesian baning Sector: A Modified VAIC (M-VAIC). Perspective. Asian Journal of Finance \& Accounting Vol. 6 No. 2. ISSN 1946-052X.

Widaryanti, 2011. Faktor-faktor yang Mempengaruhi Kinerja Intellectual Capital pada Industri Perbankan yang Listing di Bursa Efek Indonesia. Fokus Ekonomi, vol. 6 No. 1, h. 49-67.

Widyaningdyah, Agnes Utari. 2014. Intellectual Capital: Sebuah Konsep Kontemporer dan Arah Perkembangan Riset Empirisnya. Fakultas Bisnis dan Pascasarjana UKWMS. 